\title{
Pengaruh Size, Leverage, Dan Earning Power Terhadap Manajemen Laba
}

\author{
Aida Nancy ${ }^{1}$, Mohamad Zulman Hakim², Dirvi Abas ${ }^{3}$ \\ Universitas Muhammadiyah Tangerang ${ }^{1,2,3}$ \\ e-mail : aidanancy7@gmail.com (1) zulman.hakim@umt.ac.id (2)
}

\begin{abstract}
Abstrak: Salah satu parameter penting dalam mengukur kinerja manajemen adalah laba. Untuk menunjukan prestasi perusahaan dalam menghasilkan laba, manajemen cenderung mengelola laba secara oportunis dan melakukan manipulasi laporan keuangan. Penelitian ini dilakukan dengan tujuan untuk menganalisis pengaruh ukuran perusahaan, earnings power (EP), dan leverage terhadap manajemen laba. Penelitian ini menggunakan analisis regresi data panel. Ukuran perusahaan dihitung menggunakan total aset dan earnings power diproksi menggunakan net profit margin (NPM). Objek penelitian yang digunakan adalah perusahaan sektor property dan real estate dari tahun 2017 sampai dengan 2019. Hasil analisis menunjukan bahwa Ukuran Perusahaan, berpengaruh terhadap Manajemen Laba.
\end{abstract}

Kata kunci: Ukuran Perusahaan, Earnings Power, Leverage, Manajemen Laba

Laporan keuangan merupakan salah satu sarana untuk mengukur kinerja manajemen perusahaan. Salah satu parameter penting dalam laporan keuangan yang digunakan untuk mengukur kinerja manajemen adalah laba. Untuk menunjukan prestasi perusahaan dalam menghasilkan laba, manajemen cenderung mengelola laba secara oportunis dan melakukan manipulasi laporan keuangan.

Menurut Statement of Financial Accounting Concept (SFAC) No 1. Informasi laba merupakan perhatian utama untuk menaksir kinerja atau pertanggungjawaban manajemen. Selain itu informasi laba juga membantu pemilik atau pihak lain dalam menaksir earnings power perusahaan di masa yang akan datang. Laba yang dilaporkan berpengaruh kuat terhadap kegiatan perusahaan dan keputusan yang dibuat manajemen (Mulford dan Comiskey, 2012).

Laba merupakan cerminan kinerja perusahaan yang dapat dikelola secara efisien dan oportunis. Secara efisien artinya dikelola untuk meningkatkan keinformatifan informasi, dan secara oportunis artinya untuk meningkatkan laba sesuai dengan yang diinginkan dan menguntungkan pihak-pihak tertentu (Suryani, 2010). Untuk menunjukan prestasi perusahaan dalam menghasilkan laba, manajemen cenderung mengelola laba secara oportunis dan melakukan manipulasi laporan keuangan.

Tindakan oportunis tersebut dilakukan dengan cara memilih kebijakan akuntansi tertentu, sehingga laba perusahaan dapat diatur, dinaikkan maupun diturunkan sesuai dengan keinginannya. Upaya untuk mempermainkan informasi dalam laporan keuangan dengan menyembunyikan, menunda pengungkapan, dan mengubah informasi inilah yang disebut dengan manajemen laba (Sulistyanto, 2008).

Manajemen Laba didefinisikan sebagai upaya manajer perusahaan untuk mengintervensi atau memengaruhi informasi dalam laporan 
keuangan dengan tujuan untuk mengelabui stakeholder yang ingin mengetahui kinerja dan kondisi perusahaan.

Ukuran perusahaan memegang peranan penting dalam perusahaan yang melakukan praktik manajemen laba. Ukuran perusahaan yang kecil dianggap lebih banyak melakukan praktik manajemen laba dari pada perusahaan besar. Hal ini disebabkan karena perusahaan kecil cenderung ingin memperlihatkan kondisi perusahaan yang selalu berkinerja baik agar investor menanamkan modalnya pada perusahaan tersebut. Berbeda dengan perusahaan kecil, perusahaan besar biasanya akan lebih berhati-hati dalam melakukan pelaporan keuangan, karena perusahaan yang besar lebih diperhatikan oleh masyarakat. Maka ombohe, Pangemanan, danTirayoh (2014) membuktikan bahwa semakin besar ukuran perusahaan maka perilaku manajemen laba semakin berkurang.

Selain ukuran perusahaan, faktor lain yang mempengaruhi praktik manajemen laba yaitu earnings power. Dengan melakukan analisis terhadap profitabilitas perusahaan maka investor dapat menilai kemampuan perusahaan dalam menghasilkan laba (earnings power) dan sejauh mana efektifitas pengolahan perusahaan pada masa-masa yang lalu.

Leverage penting dalam mengendalikan risiko bisnis perusahaan. Jika leverage meningkat maka tingkat pengembalian (return) dan risiko perusahaan meningkat, sebaliknya penurunan leverage perusahaan akan mengakibatkan menurunnya tingkat pengembalian dan risiko perusahaan. Perusahan yang memiliki tingkat leverage yang tinggi akan cenderung melakukan manajemen laba untuk menarik kreditur.

\section{METODE}

Sampel dalam penelitian ini adalah semua perusahaan manufaktur yang terdaftar di BEl tahun 2017-2019, namun perusahaan yang tidak sesuai dengan kriteria yang ditetapkan peneliti akan dikeluarkan dari sampel. Penentuan sampel dalam penelitian ini didasarkan pada metode nonprobability sampling dengan teknik purposive sampling. yaitu sampel dipilih dengan pertimbangan tertentu atau kriteria tertentu (Sugiyono, 2013:122). Tujuan menggunakan purposive sampling adalah untuk mendapatkan sampel yang representatif sesuai dengan kriteria yang ditentukan.

Analisis statistik deskriptif adalah analisis yang digunakan untuk menilai karakteris sebuah data,karakteritikyang dimaksud adalah seperti mean, median,sum,variance,standar error, dan lainnya. Dengan menganalisis data yang telah dikumpulkan sebagaimana datanya dengan tidak membuat kesimpulan yang berlaku untuk umum atau generalisasi. Analisis statistik deskriptif memberikan deskripsi atau gambaran suatu data yang dilihat dari rata- rata (mean), standar deviasi, varian, maksimum, minimum (Warianto dan Rusiti; 2014). 
Analisis data panel adalah gabungan antara data cross section dan data time series, dimana unit cross section yang sama diukur pada waktu yang berbeda. Maka dengan kata lain, data panel merupakan data dari beberapa individu (sampel) yang diamati dalam beberapa kurun waktu tertentu (Eksandy dan Heriyanto; 2015).

$Y_{i}=\alpha+\beta_{1} X 1_{i}+\beta_{2} X 2_{i}+\beta_{3} X 3_{i}+\beta_{4} X 4_{i}+e_{i}$

Dalam mengestimasi model regresi dengan menggunakan data panel terdapat tiga pendekatan yang dapat digunakan yaitu ordinary leastsquare (OLS) atau commond effect model, metode efek tetap (fixed effect model) dan metode efek random (random effect model) (Basuki dan Prawoto;2016).

Common Effect Model merupakan pendekatan data panel yang paling sederhana. Model ini tidak memerhatikan dimensi individu maupun waktu sehingga diasumsikan bahwa perilaku antar individu sama dalam berbagai kurun waktu. Model ini mengkombinasikan antara data time series dan cross section dalam bentuk pool, mengestimasinya menggunakan pendekatan kuadrat terkecil (pooled leastsquare).

Adapun persamaan regresi dalam common effect model dapat ditulis sebagaiberikut:

Dimana:

$\mathrm{i}=$ menunjukan cross section (individu)

$\mathrm{t}=$ menunjukan periode waktu Dengan asumsi komponen error dalam

$$
Y_{i t}=\alpha+X_{i t} \beta+\varepsilon_{i t}
$$

pengolahan kuadrat terkecil biasa, proses estimasi secara terpisah untuk setiap unit crosssection dapat dilakukan (Basuki dan Prawoto ; 2016 )

\section{HASIL}

$\begin{array}{lcccc} & \text { MNJLABA } & \text { SIZE } & \text { LEVERAGE } & \text { EP } \\ \text { Mean } & 0.299375 & 0.312566 & 0.135042 & 2.532917 \\ \text { Median } & 0.261000 & 0.272950 & 0.120000 & 27.34500 \\ \text { Maximum } & 1.451230 & 0.861300 & 0.316780 & 30.50000 \\ \text { Minimum } & 0.045000 & 0.127000 & 0.010000 & 15.40000 \\ \text { Std. Dev. } & 0.233103 & 0.532166 & 0.072611 & 4.372790 \\ \text { Skewness } & 4.584753 & 0.413114 & 0.119677 & -1.216731 \\ \text { Kurtosis } & 24.13876 & 2.770350 & 2.394129 & 2.960589 \\ \text { Jarque-Bera } & 1148.356 & 3.0452252 & 1.100474 & 10.854145 \\ \text { Probability } & 0.000000 & 0.293427 & 0.192004 & 0.0323980 \\ & & & & \\ \text { Sum } & 16.07000 & 19.98000 & 6.830000 & 161.09000\end{array}$


Sum Sq.

Dev.

$$
2.55098
$$

1.89189

0.267386

492.24560

Observations 24

24

24

24 sumber : Hasil olahan eviews 0.9, 2020

pada table diatas, dapat dijelaskan bahwa jumlah data (observations) yang digunakan dalam penelitian ini adalah sebanyak 24 data. Manajemen Laba sebagai variable dependen (y) memiliki nilai terendah 0.045000 dan nilai tertinggi 1.4512300 dengan rata-rata dengan standar devisiasi 0.233103. nilai mean sebesar 0.299375 (29.93\%) menunjukan bahwa rata-rata manajemen laba perusahaan sample yang diteliti adalah $30 \%$. standar deviasi $23 \%$ menunjukan bahwa manajemen laba dari perusahaan-perusahaan sampel yang diteliti memiliki perbedaan yang relative kecil.

Tidak berpengaruhnya ukuran perusahaan terhadap manajemen laba menunjukan bahwa motivasi dewan direksi untuk melakukan manajemen laba bukan di dasarkan pada ukuran perusahaan. Keterbatasan pengetahuan setiap departemen perusahaan terhadap keuangan global mengakibatkan dewan direksi memiliki kesempatan yang besar untuk melakukan mark up terhadap laba perusahaan sehingga di mata investor kinerja perusahaan terlihat bagus.

Pengaruh leverage terhadap Manajemen laba berpengaruh positif terhadap manajemen laba Pengaruh positif dari manajemen laba menunjukan bahwa semakin tinggi nilai pendanaan asset perusahaan dari pihak ketiga atau kreditur akan mengakibatkan semakin tingginya peluang dewan direksi untuk melakukan manajemen laba. Hal ini dikarenakan ketika perusahaan memiliki tingkat leverage yang tinggi, maka perusahaan tidak lagi menggunakan pinjaman sebagai sumber dananya karena peningkatan jumlah pinjaman akan meningkatkan resiko kebangkrutan perusahaan, sehingga perusahaan akan lebih tertarik untuk meningkatkan pendanaan ekuitasnya.

Pengaruh Earnings Power berpengaruh positif terhadap manajemen laba Berpengaruhnya secara positif menunjukan earnings power perusahaan akan mengakibatkan peningkatan terhadap kesempatan atau peluang bagi dewan direksi untuk melakukan manajemen laba. Meskipun laporan keuangan menyajikan apa yang telah terjadi tetapi profitabilitas di waktu lalu dapat memproyeksikan tingkat profitabilitas masa yang akan datang. Untuk memberikan ketertarikan kepada investor, manajer perlu melakukan manajemen laba agar dapat membuktikan kepada investor bahwa laba tahun ini lebih baik dari laba tahun sebelumnya.

\section{KESIMPULAN}

Berdasarkan hasil penelitian dan pembahasan pada bagian sebelumnya, maka penelitian ini dapat disimpulkan bahwa besarnya 
tingkat rasio leverage dan earnings power perusahaan berpengaruh terhadap terjadinya tindak manajemen laba sedangkan ukuran perusahaan tidak mempengaruhi terjadinya tindak manajemen laba.

\section{DAFTAR PUSTAKA}

Hastuti, Sri. 2011. Titik Kritis Manajemen

Laba pada Perubahan Tahap Life Cycle Perusahaan. Prosiding, Simposium Nasional Akuntansi Aceh 21-22 Juli 2011

Nastiti, A. S. dan Tatang, A. G. 2011. Kualitas audit dan Manajemen Laba pada Initial Public Offerings di Indonesia, Prosiding, Simposium Nasional Akuntansi XIV. Aceh, 21 - 22 Juli 2011

Henny Medyawati, Astri Sri Dayanti, Pengaruh Size terhadap manajemen laba: Analisi Data Panel

Santhi Yuliana Sosiawan, Pengaruh Earning Power, Size dan Kompensasi terhadap Manajemen Laba

Bursa Efek Indonesia selama periode 2017 sampai dengan 2019; 2)

Widyaningdyah, A. U. 2001. Analisis FaktorFaktor Yang Berpengaruh Terhadap Earnings Management pada Perusahaan Go Publik di Indonesia. Jurnal Akuntansi Keuangan. 